\title{
Use of Immobilized Amine Transaminase from Vibrio fluvialis under Flow Conditions for the Synthesis of (S)-1-(5- Fluoropyrimidin-2-yl)-ethanamine
}

\author{
Riccardo Semproli ${ }^{+}{ }^{[a]}$ Gianmarco Vaccaro $^{+}{ }^{[a, b]}$ Erica E. Ferrandi, ${ }^{[c]}$ Marta Vanoni, ${ }^{[c]}$ \\ Teodora Bavaro, ${ }^{[\mathrm{ac}}$ Giorgio Marrubini, ${ }^{[\mathrm{a}]}$ Francesca Annunziata, ${ }^{[\mathrm{b}]}$ Paola Conti, ${ }^{[\mathrm{b}]}$ \\ Giovanna Speranza, ${ }^{[\mathrm{d}]}$ Daniela Monti, ${ }^{[\mathrm{[c]}}$ Lucia Tamborini, ${ }^{*[b]}$ and Daniela Ubiali ${ }^{*[a]}$
}

We report on the covalent immobilization of the (S)-selective amine transaminase from Vibrio fluvialis (Vf-ATA) and its use in the synthesis of (S)-1-(5-fluoropyrimidin-2-yl)-ethanamine, a key intermediate of the JAK2 kinase inhibitor AZD1480. Immobilized Vf-ATA on glyoxyl-agarose (activity recovery: $30 \%$ ) was used in a packed-bed reactor to set-up a continuous flow biotransfor- mation coupled with a straightforward in-line purification to circumvent the 2-step process described in literature for the batch reaction. The newly developed biotransformation was run in a homogeneous system including dimethyl carbonate as a green co-solvent. Optically pure (S)-1-(5-fluoropyrimidin-2-yl)ethanamine (ee $>99 \%$ ) was isolated in $35 \%$ yield.

\section{Introduction}

Amine transaminases (ATAs, EC 2.6.1.x) catalyze the enantioselective amination of ketones by utilizing simple amines as amino donors and the vitamin $\mathrm{B}_{6}$-based pyridoxal 5-phosphate (PLP) cofactor as a molecular shuttle. ${ }^{[1-4]}$ Since the first characterization of these enzymatic activities in the late $90 \mathrm{~s}^{\left[{ }^{[5]}\right.}$ ATAs have been intensively investigated for the synthesis of chiral amines. These molecules are valuable building blocks for the preparation of APIs including antiarrhythmics (e.g. vernakalant), antibiotics (e.g. moxifloxacin), anti-epilepsy agents (e.g. levetiracetam and pregabalin), and antidiabetics (e.g. sitagliptin). ${ }^{[6]}$ Among the examples of ATAs application on an

[a] R. Semproli, ${ }^{+}$G. Vaccaro, ${ }^{+}$Dr. T. Bavaro, Dr. G. Marrubini, Prof. D. Ubiali Department of Drug Sciences

University of Pavia

Viale Taramelli 12

Pavia I-27100 (Italy)

E-mail: daniela.ubiali@unipv.it

[b] G. Vaccaro, ${ }^{+}$F. Annunziata, Prof. P. Conti, Prof. L. Tamborini

Department of Pharmaceutical Sciences

University of Milano

Via Mangiagalli 25

Milano I-20133 (Italy)

E-mail: lucia.tamborini@unimi.it

[c] Dr. E. E. Ferrandi, M. Vanoni, Dr. D. Monti

Istituto di Scienze e Tecnologie Chimiche "Giulio Natta" (SCITEC) - CNR

Via Bianco 9

Milano l-20131 (Italy)

E-mail: daniela.monti@scitec.cnr.it

[d] Prof. G. Speranza

Department of Chemistry

University of Milano

Via Golgi 19

Milano I-20133 (Italy)

$\left.{ }^{+}\right]$These authors contributed equally to this work.

Supporting information for this article is available on the WWW under https://doi.org/10.1002/cctc.201902080

This publication is part of a joint Special Collection with ChemBioChem on "Excellence in Biocatalysis Research". Please follow the link for more articles in the collection. industrial scale, ${ }^{[7-12]}$ a milestone was placed by Merck and Codexis 10 years ago with the synthesis by transamination of sitagliptin (Januvia ${ }^{\oplus}$ ), the first marketed oral antihyperglycemic drug belonging to the gliptin family. This bioprocess allowed the replacement of a high-pressure rhodium-catalyzed asymmetric enamine hydrogenation step by applying a highly engineered ATA variant. ${ }^{[7]}$ Later on, a number of reports about ATA immobilization for the synthesis of this API were released. ${ }^{[13-16]}$ These outstanding achievements have demonstrated that, if optimized, ATA-based enzymatic platforms can be competitive with the established manufacture processes, since align selectivity, efficiency and sustainability. ${ }^{[17]}$

Another example of a pre-industrial ATA-catalyzed process was developed by AstraZeneca for the production of (S)-1-(5fluoropyrimidin-2-yl)-ethanamine (3, Scheme 1A), a key intermediate in the synthesis of the JAK2 kinase inhibitor AZD1480, a molecule targeting idiopathic myelofibrosis and polycythaemia rubra vera. ${ }^{[9,18]}$ The well-known ATA from Vibrio fluvialis (VfATA $)^{[19-22]}$ was selected among 60 transaminases; process conditions were optimized on a gram scale starting from the fluorinated ketone (1) and using (S)- $\alpha$-methylbenzylamine (2, (S)-MBA) as the amino donor.

The reaction was performed in a biphasic system by using toluene to pull out the co-product acetophenone (4). The continuous extraction was necessary to shift reaction equilibrium and to avoid product inhibition effects. ${ }^{[18]}$ Since the synthesized amine is water soluble, the purification protocol relies on the conversion of the amine to the corresponding Bocderivative followed by extraction and precipitation of the amine hydrochloride with $\mathrm{HCl}$ in iso-propanol. Besides co-product removal through the use of a biphasic system as described above, unfavorable reaction equilibrium of ATA-catalyzed amine synthesis as well as product inhibition suffered by these enzymes have been managed in different ways. The use of amino donors in large excess combined with the in situ removal of amine-derived by-products have been pursued, either 


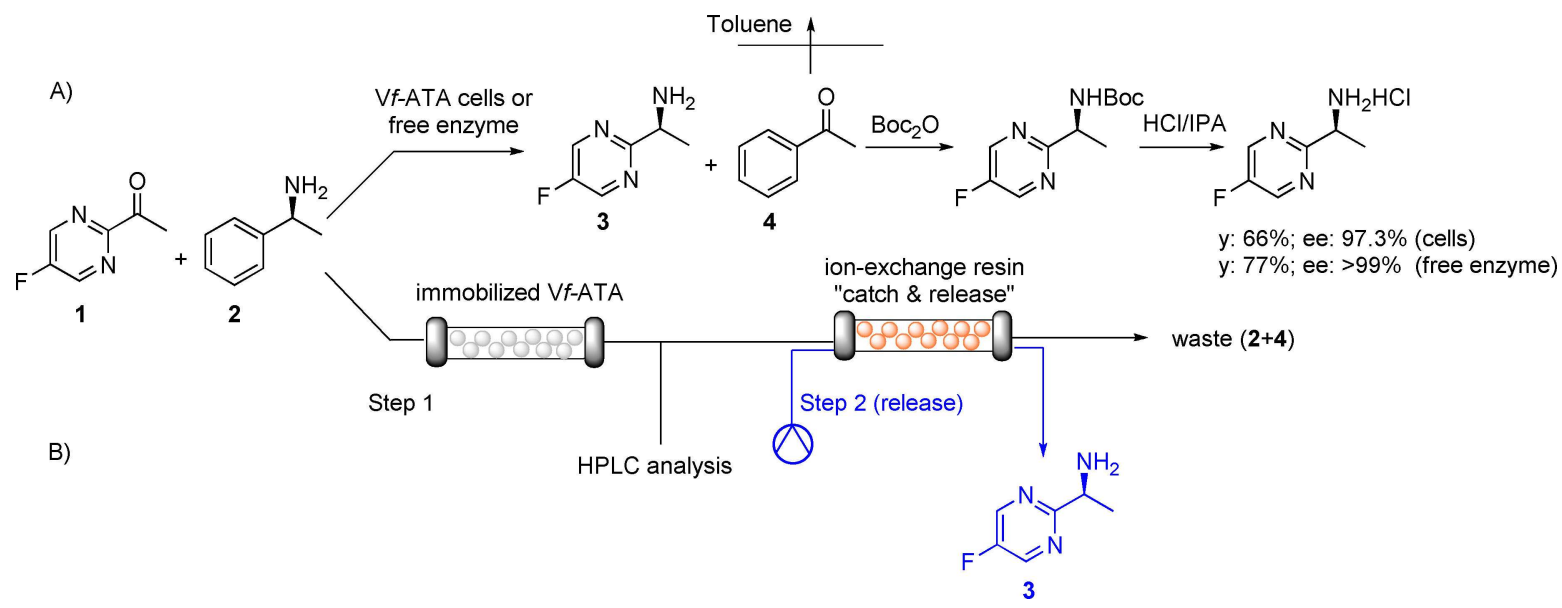

Scheme 1. Synthesis of (S)-1-(5-fluoropyrimidin-2-yl)-ethanamine (3) catalyzed by Vf-ATA. A) Synthetic route as reported in Ref. [18]. B) Synthetic route investigated in the present work.

through an ancillary enzymatic reaction, or by exploiting specific diamines generating by-products that spontaneously undergo cyclization/tautomerization. ${ }^{[23-24]}$

Given the increasing evidences supporting the use of biocatalysis for industrial scale synthesis of APIs, a number of innovative technologies have been considered as complementary tools for the development of intensified and industrially relevant biocatalytic processes. In particular, there is a growing interest in performing biocatalyzed transformations in continuous flow reactors. ${ }^{[25-28]}$ Both biocatalysis and continuous processing do have the features that make these technologies as the foremost key green research areas for sustainable manufacturing of APIs and fine chemicals. Biocatalysts, either enzymes or whole cells, are typically immobilized onto the reactor wall or on particles of a carrier material, which is then packed into a column to form a packed-bed reactor with a plug-flow behavior. ${ }^{[29]}$ Among the various methods for enzyme immobilization, covalent immobilization is probably the most successful approach, allowing a robust attachment of the enzyme. Powdery materials can be used as carriers and packed in a fixed bed reactor as well as porous monoliths, which have been successfully used for ATA immobilization. ${ }^{[30-31]}$ Flow chemistry, along with enzyme immobilization, can circumvent some critical issues of biocatalytic reactions, thus positively influencing the outcome of the biotransformation. ${ }^{[32]}$ In particular, whereas enzyme immobilization can improve enzyme stability, operating under flow-conditions can significantly reduce substrate/product inhibition effects and push forward unfavorable reaction equilibria through the continuous removal of the product from the reaction site. Moreover, a better process control makes the reaction more efficient and minimizes waste generation.

Based on these premises, we developed a new protocol integrating flow biocatalysis with downstream processing for the end-to-end synthesis of (S)-1-(5-fluoropyrimidin-2-yl)-ethanamine (3), using immobilized Vf-ATA as the biocatalyst.

\section{Results and Discussion}

The amine transaminase from Vibrio fluvialis (Vf-ATA) was successfully produced by recombinant expression in E. coli BL21 (DE3) cells from the corresponding codon-optimized synthetic gene (GenBank AEA39183.1). Subsequent purification by nickelnitrilotriacetic acid (Ni-NTA) chromatography afforded $80 \mathrm{mg}$ of pure protein from $1 \mathrm{~L}$ culture (Supporting Information, Figure S1). The specific activity of the purified enzyme was determined spectrophotometrically in the transamination reaction between the benchmark substrates (S)-MBA (2) and pyruvate (Supporting Information, Scheme S1). Two different carriers were chosen for the immobilization: glyoxyl-agarose and Sepabeads ${ }^{\mathrm{TM}}$ EC-EP/S. Both carriers rely on the covalent interaction enzyme-support and have been demonstrated to be versatile for the immobilization of many enzymes. ${ }^{[3-34]}$ Moreover, both glyoxyl-agarose and Sepabeads ${ }^{\mathrm{TM}}$ EC-EP/S have been successfully applied to biotransformations under flow conditions. ${ }^{[35-36]}$

\section{Vf-ATA immobilization on glyoxyl-agarose}

The immobilization of Vf-ATA on glyoxyl-agarose was performed at $\mathrm{pH} 10$ to obtain a "multi-point" interaction through the lysine residues of the enzyme and the aldehyde groups of the carrier. The resulting enzyme-carrier bonds are weak Schiff bases and are thus reversible. Chemical reduction of the immobilized enzyme (usually by $\mathrm{NaBH}_{4}$ or $\mathrm{NaCNBH}_{3}$ ) is frequently applied ${ }^{[37-38]}$ to convert enzyme-carrier bonds into stable secondary amino groups (Scheme $2 \mathrm{~A}$ ).

This immobilization protocol gave quantitative yields in terms of immobilized protein and immobilized activity: at the endpoint $(3 \mathrm{~h})$ neither residual protein nor activity were found in the supernatant, but the activity recovery was very poor (3\%). 
A)

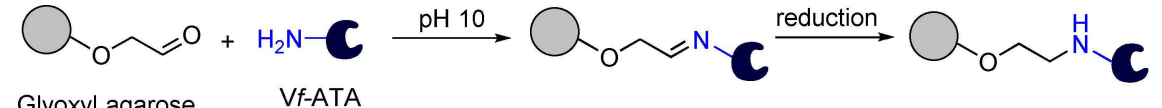

Glyoxyl agarose

VF-ATA

B)

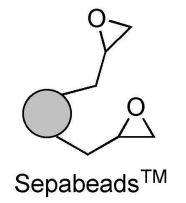

EC-EP/S

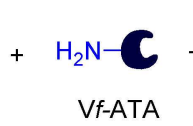

Vf-ATA

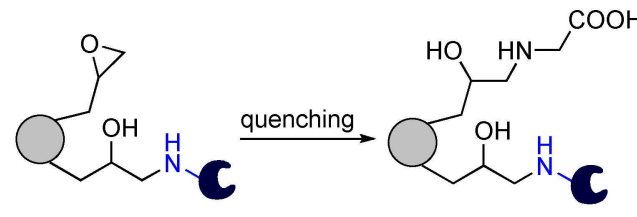

Scheme 2. Vf-ATA immobilization. A) Immobilization on glyoxyl-agarose was performed in sodium bicarbonate (pH 10, $50 \mathrm{mM}$ ) under mechanical stirring (protein loading: $2 \mathrm{mg} \mathrm{g}^{-1}$; carrier/total volume: $1 \mathrm{~g} / 10 \mathrm{~mL}$ ). Experiments were performed at $4{ }^{\circ} \mathrm{C}$ or r.t. for $3 \mathrm{~h}$, with or without glycerol $\left(20 \% \mathrm{v} / \mathrm{v}\right.$ ). NaBH $\mathrm{H}_{4}$ or $\mathrm{NaCNBH}_{3}\left(1 \mathrm{mg} \mathrm{mL}^{-1}\right)$ was used as reducing agent. B) Immobilization on Sepabeads ${ }^{\mathrm{TM}}$ EC-EP/S was performed in phosphate buffer (pH 8.0, 50 mM) under mechanical stirring (protein loading: $1 \mathrm{mg} \mathrm{g}^{-1}$; carrier/total volume:1 g/10 mL). Experiments were performed at r.t for $24 \mathrm{~h}$. Quenching was performed with $3 \mathrm{M}$ glycine in phosphate buffer $(\mathrm{pH} 8.5,50 \mathrm{mM}, 4 \mathrm{~mL})$ under mechanical stirring at r.t. for $20 \mathrm{~h}$.

However, the activity assay performed on the immobilization suspension when the supernatant was already non-active, but before adding the reducing agent, showed activity (data not shown), thus suggesting that the reduction step might be the cause of enzyme inactivation. To confirm whether the reduction was the critical step, three immobilization trials were performed in parallel by following the protocol described in the Experimental Section. When both protein content and activity were negligible in the supernatant $(3 \mathrm{~h})$, two aliquots of the same immobilized biocatalyst were reduced with either $\mathrm{NaBH}_{4}$ or $\mathrm{NaCNBH}_{3}$, respectively, whereas the third aliquot was not reduced (Figure $1 \mathrm{~A})$. The presence of the cyano group in $\mathrm{NaCNBH}_{3}$ makes this reducing agent milder than $\mathrm{NaBH}_{4}$ i in fact, $\mathrm{NaCNBH}_{3}$ is generally used to selectively reduce imines even in presence of aldehydes and ketones under neutral or weakly acid conditions. Although in all cases the activity recovery was $<10 \%$, the highest activity recovery was obtained for the nonreduced biocatalyst and when the reduction was performed by using $\mathrm{NaCNBH}_{3}$. Since the reversibility of the imine groups could be a limitation in the use of the immobilized enzyme, $\mathrm{NaCNBH}_{3}$ was selected as the reducing agent for the following
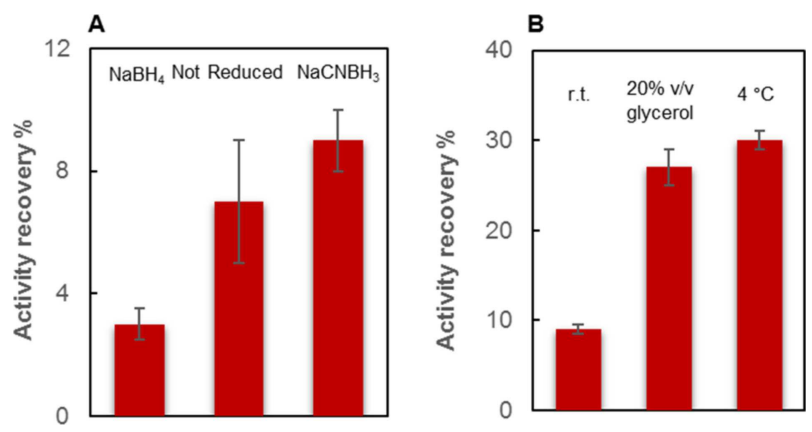

Figure 1. A) Effect of the reducing agent on the activity recovery (observed activity/starting activity) $\times 100$. B) Effect of glycerol and temperature on the activity recovery $\left(\mathrm{NaCNBH}_{3}\right)$. These immobilization experiments were performed with $0.5 \mathrm{~g}$ of glyoxyl-agarose in a final volume of $5 \mathrm{~mL}$ by using the same protein loading $\left(2 \mathrm{mg} \mathrm{g}^{-1}\right)$, activity loading $\left(4.58 \mathrm{U} \mathrm{g}^{-1}\right)$ and run time $(3 \mathrm{~h})$. For the reduction step, $5 \mathrm{mg}$ of the reducing agent were added and the mixture was stirred for further $30 \mathrm{~min}$. immobilization trials. To further increase the activity recovery of the immobilized Vf-ATA, the effect of glycerol and temperature were evaluated (Figure 1B).

In fact, glycerol is routinely used to preserve proteins under storage.$^{[39]}$ For this reason, glycerol has been used as an additive in some immobilization procedures; typically, the amount of glycerol does not exceed $20 \% \mathrm{v} / \mathrm{v}^{[40]}$ Furthermore, a recent report on Vf-ATA thermostability ${ }^{[41]}$ showed that this enzyme retains $100 \%$ activity at $4{ }^{\circ} \mathrm{C}$ for more than $50 \mathrm{~h}$, and $80 \%$ activity when it is incubated at $25-37^{\circ} \mathrm{C}$. In the presence of glycerol $(20 \% \mathrm{v} / \mathrm{v})$ and at low temperature $\left(4^{\circ} \mathrm{C}\right)$, the yields in terms of immobilized protein and activity remained quantitative and both the immobilization experiments showed a remarkable increase of the activity recovery (around $30 \%$, Table S1). From these results, $4{ }^{\circ} \mathrm{C}$ and $\mathrm{NaCNBH}_{3}$ as the reducing agent were selected for the following immobilization experiments. The activity recovery (30\%) was considered suitable to switch from batch to flow applications, in agreement with previous reports. ${ }^{[36]}$ Immobilization results for glyoxyl-agarose are summarized in Figure 1.

\section{Stability assay of Vf-ATA immobilized on glyoxyl-agarose}

The immobilized enzyme must be active at least for the time required by the reaction to be completed. However, it is desirable that the biocatalyst maintains its activity for a longer period, thus allowing its reuse for more reaction cycles. Vf-ATA immobilized on glyoxyl-agarose (at $4^{\circ} \mathrm{C}$ and reduced with $\mathrm{NaCNBH}_{3}$ ) was incubated with the reaction mixture containing all the reactants with the exception of the prochiral ketone (1, amino acceptor) due to its high cost. The immobilized biocatalyst maintained about $50 \%$ of the starting activity after $72 \mathrm{~h}$ (Figure 2).

Although a striking difference of stability between native and immobilized enzyme did not emerge, the clear advantage of the immobilized biocatalyst is its easier separation from the reaction medium and application for in continuum biotransformations. 


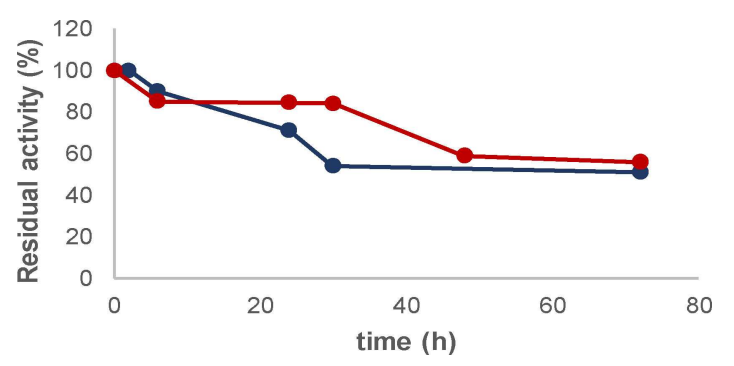

Figure 2. Stability of Vf-ATA immobilized on glyoxyl-agarose (blue) compared to free $V f$-ATA (red). Experimental conditions: phosphate buffer $(\mathrm{pH} 8.0,100 \mathrm{mM})$ containing DMSO $(2 \% \mathrm{v} / \mathrm{v})$ in the presence of $10 \mathrm{mM}(S)$ MBA and $1 \mathrm{mM}$ PLP. Immobilized Vf-ATA: $50 \mathrm{mg}$, final volume: $1 \mathrm{~mL}$; free $V f$ ATA: $2.6 \mathrm{mg}$, final volume: $3 \mathrm{~mL}$. The residual activity was determined by the spectrophotometric assay (see Experimental Section).

\section{Vf-ATA immobilization on Sepabeads ${ }^{\mathrm{TM}}$ EC-EP/S}

Besides glyoxyl-agarose, epoxy carriers are probably the most used supports to immobilize enzymes. These resins do not need to be pre-activated since epoxides act as the reactive groups. ${ }^{[34]}$ Thus, immobilization of Vf-ATA was also performed on Sepabeads ${ }^{\mathrm{TM}}$ EC-EP/S. Enzymes bind covalently to this support by exploiting the nucleophilic features of lysine $\varepsilon$-amino groups, thus generating a multi-point interaction (as for glyoxyl-agarose). In this case, a stable secondary amine bond is formed without the need for any further step (Scheme 2B). However, epoxides are much more reactive than aldehydes and may still react either with the protein, even after the immobilization, or with substrates and/or products of the target reaction. For this reason, unreacted epoxy groups of Sepabeads ${ }^{\mathrm{TM}} \mathrm{EC}$-EP/S must be quenched in order to avoid sidereactions. ${ }^{[42-43]}$ Glycine was chosen for the post-immobilization quenching according to a literature protocol in which a derivatized Sepabeads ${ }^{\mathrm{TM}}$ EC-EP/S was used to immobilize the transaminase from Halomonas elongata (HEWT). ${ }^{[36]}$ The efficient immobilization of an engineered ATA mutant from Chromobacterium violaceum on a properly designed epoxy-functionalized carrier has been also recently described for continuous-flow applications. ${ }^{[44]}$

Vf-ATA immobilization on Sepabeads ${ }^{\text {TM }}$ EC-EP/S gave quantitative yields in terms of immobilized protein and immobilized activity after $24 \mathrm{~h}$ incubation. The activity of this biocatalyst was determined by a discontinuous assay because, unlike glyoxylagarose, epoxy-acrylic carriers are bead-like materials that interfere with the spectrophotometric analysis. Although the activity of Vf-ATA immobilized on Sepabeads ${ }^{\mathrm{TM}}$ EC-EP/S was remarkable (activity recovery: $\approx 50 \%$, Table S2), it was observed that acetophenone (4), i.e. the product of the investigated biotransformation, was adsorbed by the carrier, thus affecting its accurate quantification. The quenching with glycine increased the hydrophilicity of the carrier, thus decreasing (but not eliminating) the acetophenone adsorption. This adsorption phenomenon was confirmed by incubating Sepabeads ${ }^{\mathrm{TM}}$ EC$\mathrm{EP} / \mathrm{S}$ (without the enzyme) with a solution of acetophenone at a known concentration and monitoring the supernatant absorbance at $245 \mathrm{~nm}$ over time (data not shown).

Taking in consideration this phenomenon, glyoxyl-agarose appeared a more convenient carrier due to the acceptable activity recovery and stability. Moreover, this carrier was already shown to be suitable for flow applications. ${ }^{[35]}$

\section{Batch synthesis of (S)-1-(5-fluoropyrimidin-2-yl)-ethanamine}

(3)

The enzymatic synthesis of (S)-1-(5-fluoropyrimidin-2-yl)-ethanamine (3) was performed by using Vf-ATA immobilized on glyoxyl-agarose in view of transferring the bioconversion from batch to a flow system. As a preliminary approach, the amination of the non-fluorinated ketone was carried out with the aim of exploring the reaction conditions, testing the feasibility of the bioconversion with the newly immobilized enzyme, and setting-up a downstream process that might be more straightforward than that described in literature. ${ }^{[18]}(S)$ MBA (2) was selected as the amino donor because it was also used in the activity assay and it is commonly used as benchmark substrate with (S)-selective transaminases (both in batch and in flow systems)..$^{[20,36,45]}$ Moreover, (S)-MBA is the amino donor used in the synthesis of (S)-1-(5-fluoropyrimidin-2-yl)ethanamine reported by Meadows et al. ${ }^{[18]}$ The reaction was performed at $\mathrm{pH} 8$, according to the enzymatic assay conditions (see also Figure S2). In contrast to literature, ${ }^{[18]}$ in this work a monophasic system containing DMSO (2\%) as the co-solvent was used. As reported in Table 1, a $30 \%$ conversion was observed which was comparable with the results obtained with the non-fluorinated ketone (data not shown). Conversions (\%) were calculated by HPLC, using the acetophenone calibration curve.

After the reaction, the biocatalyst was easily separated from the reaction mixture by filtration and showed a residual activity of $50 \%$. This result was consistent with the stability assay of the immobilized Vf-ATA. Furthermore, no protein release was detected in the reaction (Bradford assay), ${ }^{[46]}$ as a consequence of the covalent immobilization.

The data obtained in the batch reaction were considered suitable to switch the bioconversion to a flow system and thus to run the study both of the reaction and the downstream in such a set-up.

\begin{tabular}{|c|c|c|c|c|}
\hline $\begin{array}{l}\text { Substrate } \\
{[\mathrm{mM}]}\end{array}$ & $\begin{array}{l}\text { Vf-ATA } \\
{[\mathrm{U}]^{[\mathrm{a}]}}\end{array}$ & $\begin{array}{l}\text { Ratio } \\
\text { [acceptor: do- } \\
\text { nor] }\end{array}$ & $\begin{array}{l}\text { Conversion } \\
{[\%]^{[b]}}\end{array}$ & $\begin{array}{l}\text { Time } \\
\text { [h] }\end{array}$ \\
\hline 20 & 1.80 & $1: 1$ & 30 & 31 \\
\hline \multicolumn{5}{|c|}{$\begin{array}{l}\text { [a] The biocatalyst was immobilized at } 4{ }^{\circ} \mathrm{C} \text { and } \mathrm{NaCNBH}_{3} \text { was used as the } \\
\text { reducing agent. Protein loading: } 2 \mathrm{mg} \mathrm{g}^{-1} \text {; activity recovery: } 30 \% \text {. The } \\
\text { specific activity, determined by spectrophotometric assay, was } 2.76 \mathrm{Ug}^{-1} \text {, } \\
\text { [b] Conversion was calculated by HPLC. The reaction was performed in } \\
\text { duplicate. }\end{array}$} \\
\hline
\end{tabular}


Flow synthesis of (S)-1-(5-fluoropyrimidin-2-yl)-ethanamine (3)

A packed-bed reactor with immobilized Vf-ATA was prepared for the continuous flow application. First, the effect of residence time and temperature on the reaction outcome was evaluated using a $0.65 \mathrm{~mL}$ volume bioreactor (immobilized Vf-ATA $=$ $0.65 \mathrm{~g})$ and flowing through it a solution of 1-(5-fluoropyrimidin-2-yl)-ethan-1-one (1, $20 \mathrm{mM})$, (S)-MBA (2, $20 \mathrm{mM})$ and PLP $(1 \mathrm{mM})$ in phosphate buffer $(100 \mathrm{mM}, \mathrm{pH}$ ) containing DMSO $(2 \% \mathrm{v} / \mathrm{v})$. Conversions (\%) were calculated by HPLC, using the acetophenone calibration curve. As reported in Table 2, a 40\% conversion was achieved in 10 minutes of residence time (entry 2); a further increase of the residence time was not beneficial (entries 3 and 4). Keeping constant the residence time (10 min), concentration of the substrates in the feeding flow was varied, but the conversion was dramatically reduced (entry 6). Also, an increase of the temperature up to $38^{\circ} \mathrm{C}$ did not speed up the reaction (entry 5).

Under a similar degree of conversion (i.e. $\mathrm{c}=30 \%$ after $31 \mathrm{~h}$ for the batch biotransformation and $c=26 \%$ in 5 minutes for the flow biotransformation), the specific reaction rate $(r)$ of the flow reaction resulted to be about 22 -fold higher than the batch reaction $\quad\left(r_{\text {flow }}=0.52 \mu \mathrm{mol} \mathrm{min}-1 \mathrm{mg}^{-1} ; \quad r_{\text {batch }}=\right.$ $0.024 \mu \mathrm{mol} \mathrm{min} \mathrm{mg}^{-1} \mathrm{mg}^{-1}$, probably due to the high local concentration of the biocatalyst in the packed-bed reactor. ${ }^{[47]}$

To increase the sustainability of the proposed protocol, we tested dimethyl carbonate as the co-solvent $(5 \% \mathrm{v} / \mathrm{v})$ for the flow reaction and evaluated the reaction outcome under continuous work.

To this aim, a $2 \mathrm{~mL}$ bioreactor was prepared and $100 \mathrm{~mL}$ of the substrate solution was flowed through it under the following conditions: residence time $=10 \mathrm{~min}, \mathrm{~T}=28^{\circ} \mathrm{C}, \mathrm{P}=$ atm. Overall, a $38 \%$ conversion was obtained. Finally, an in-line purification procedure for product isolation was developed (Scheme 1B).

A first attempt to extract the produced amine using an inlet of an organic solvent (i.e. EtOAc) and a membrane phase separator was performed. However, only a low amount of (S)-1(5-fluoropyrimidin-2-yl)-ethanamine (3) was recovered in the organic phase $(<5 \%)$. Therefore, we exploited a catch-andrelease strategy, using a column packed with a strongly acidic

\begin{tabular}{|c|c|c|c|c|}
\hline Entry & $\begin{array}{l}\text { Substrate } \\
{[\mathrm{mM}]}\end{array}$ & $\begin{array}{l}\text { Residence time } \\
\text { [min] }\end{array}$ & $\begin{array}{l}\text { Temperature } \\
{\left[{ }^{\circ} \mathrm{C}\right]}\end{array}$ & $\begin{array}{l}\text { Conversion } \\
{[\%]^{[b]}}\end{array}$ \\
\hline 1 & 20 & 5 & 28 & 26 \\
\hline 2 & 20 & 10 & 28 & 40 \\
\hline 3 & 20 & 15 & 28 & 39 \\
\hline 4 & 20 & 30 & 28 & 39 \\
\hline 5 & 20 & 10 & 38 & 38 \\
\hline 6 & 40 & 10 & 28 & 17 \\
\hline
\end{tabular}

[a] Immobilized Vf-ATA: $0.65 \mathrm{~g}$; reactor volume: $0.65 \mathrm{~mL}$; ratio acceptor/ donor 1:1; PLP 1 mM; flow stream: phosphate buffer (100 mM, pH 8.0) containing DMSO $(2 \% \mathrm{v} / \mathrm{v})$; atmospheric pressure, $[\mathrm{b}]$ Conversion was calculated by HPLC. resin (Dowex Marathon C) to trap any unreacted (S)-MBA and the desired amine. Then, after a washing step with distilled water, an inlet of aqueous ammonia (1 M) was used to release the amine product that, due to the different pka compared to (S)-MBA, was collected separately and isolated in $35 \%$ yield.

\section{Determination of the enantiomeric excess of (S)-1-(5-fluoropyrimidin-2-yl)-ethanamine (3)}

Upon in-line purification, the target amine was submitted to a HPLC chiral analysis to assess the enantiomeric excess. The absolute configuration of a chiral amino donor has to match the stereospecificity of the ATAs in order to be accepted: this feature explains why transaminases can be employed in the kinetic resolution of racemic amines. ${ }^{[48]}$ For this reason, Vf-ATA, which is a (S)-selective ATA, should not be able to produce amines with $(R)$-configuration. Surprisingly, the chiral HPLC analysis of the amine synthesized enzymatically did result in a $90 \%$ enantiomeric excess for the S-enantiomer which was totally unexpected. To shed light on this result, new experiments were performed. Taking into account that both immobilization and the presence of organic co-solvents can alter enzyme selectivity, ${ }^{[49-50]}$ the reaction was repeated both by using the non-immobilized enzyme and either DMSO or dimethyl carbonate as co-solvent. However, it is worth to underline that, to the best of our knowledge, decrease and/or inversion of enantioselectivity have never been reported for transaminases.

The biotransformation performed in batch by using the soluble Vf-ATA under the same conditions of the flow reaction (donor and acceptor: $200 \mu \mathrm{mol}$; PLP: $20 \mu \mathrm{mol}$; medium: $100 \mathrm{mM}$ phosphate buffer, $\mathrm{pH} 8.0,5 \% \mathrm{v} / \mathrm{v}$ dimethyl carbonate) gave the same ee\% (90\%): this result thus ruled out the influence of immobilization on the incomplete (S)-enantioselectivity of $V f$ ATA.

The same result was obtained upon analyzing the reaction mixtures containing two different co-solvents (DMSO and dimethyl carbonate, respectively), thus excluding a role of these solvents, too.

Our attention was then focused on PLP, the co-factor of ATAs. PLP is an activated aldehyde and the formation of imines is its natural role. It has been reported that PLP, upon the formation of a Schiff base with $\alpha$-amino acid esters or amines, enhances racemization through a reversible proton migration. ${ }^{[1]}$ This phenomenon has been exploited for the dynamic resolution of a number of racemic substrates. ${ }^{[52-54]}$ The hypothesized mechanism of PLP toward (S)-1-(5-fluoropyrimidin-2-yl)-ethanamine (3) is reported in Scheme S2 (Supporting Information).

The chiral analysis of a batch biotransformation which was performed without adding PLP showed a complete ee\%, thus supporting our hypothesis concerning the role of PLP in the amine racemization. In this case, the $(S)$-amine formation catalyzed by Vf-ATA relies exclusively on the PLP intrinsically bound to Vf-ATA. We concluded, indeed, that the driving force of the side-reaction was the concentration of PLP used in the 
reactions (1-2 $\mathrm{mM}$ ) which is probably uselessly high for the biotransformation, although consistent with other reports on transaminases. ${ }^{[55-58]}$ Furthermore, the hypothesized mechanism might be enhanced by the alkaline $\mathrm{pH}$ of the reaction mixture: at this $\mathrm{pH}$ value (around 8-9), ATAs show the highest activity, but amines are predominant in their neutral form. Thus, the nucleophilic reaction of amines with the PLP aldehyde group is plausible to occur. On the other hand, although the absence of PLP in the reaction mixture allowed to restore the complete enantioselectivity of Vf-ATA and to achieve a ee $>99 \%$, this condition was detrimental for the biocatalyst. After this reaction, immobilized Vf-ATA lost almost completely its activity. The concentration of PLP is therefore a crucial parameter which deserves to be further investigated.

In this context, we tested the reaction without PLP under continuous flow using the conditions reported above. However, a very low conversion $(<5 \%)$ was obtained. Therefore, increasing amounts of PLP (i.e., $0.1 \mathrm{mM}$ and $0.25 \mathrm{mM}$ ) were added to the substrate solution that was flowed through the bioreactor and the performance of the biotransformation was evaluated. Using $0.1 \mathrm{mM}$ PLP, again, a very low conversion in 10 minutes of residence time was observed, whereas, using $0.25 \mathrm{mM} \mathrm{PLP}$, a conversion comparable to the previous experiments (38\%) was achieved. The amine was isolated as reported above and the enantiomeric excess was assessed by chiral HPLC, resulting to be $>99 \%$.

It is worth reporting that the use of tailor-made carriers which can enable the co-immobilization of transaminase and PLP has been recently described. ${ }^{[38]}$ Through this strategy, the exogenous addition of cofactor is avoided, since a self-sufficient source of PLP is ensured by the co-immobilized preparation for an efficient catalysis.

\section{Conclusions}

A new protocol for the synthesis of (S)-1-(5-fluoropyrimidin-2yl)-ethanamine (3), which integrates flow biocatalysis with an in-line downstream processing, was successfully developed.

The main benefits of the set-up herein described include the increased specific reaction rate in comparison with the batch protocol and a significantly reduced time of the overall process (reaction and product recovery). Interestingly, a possible role played by the cofactor PLP in transaminasecatalyzed amination of ketones was highlighted; albeit essential for the catalysis, PLP seemed to affect the enantioselectivity of the transamination reaction and, indeed, its concentration needs to be finely tuned. These results demonstrated that the combination of biocatalysis and flow chemistry should be regarded as a truly competitive approach with established fully chemical protocols.

\section{Experimental Section}

\section{General}

All reagents and solvents were purchased from Sigma-Aldrich ${ }^{\oplus} \mathrm{Srl}$ (Milan, Italy) unless otherwise stated. 1-(5-Fluoropyrimidin-2-yl)ethan-1-one (1) was purchased from Fluorochem (Hadfield, UK). For the production, purification and characterization of the enzyme, the following instruments were used: Thermoshaker INNOVA 42 (New Brunswick); Sorvall RC6 Plus (Thermo) centrifuge, A.L.C. 4226 centrifuge, Omni-Ruptor 250 sonicator, UV-VIS V-530 (Jasco) spectrophotometer or a UV 1601 spectrophotometer (Shimadzu).

Agarose gel $6 \mathrm{~B}-\mathrm{CL}$ was purchased from Amersham Biosciences (Uppsala, Sweden) and activated to glyoxyl-agarose as previously reported. ${ }^{[59]}$ Sepabeads ${ }^{\mathrm{TM}}$ EC-EP/S was kindly supplied by Resindion srl (Binasco, Italy).

The flow experiments were performed by using a $\mathrm{R} 2+/ \mathrm{R} 4$ flow reactor (Vapourtec).

\section{Immobilization yields}

The immobilization yields (\%) were determined as: immobilized protein, immobilized activity and activity recovery as reported by Sheldon et al. ${ }^{[60]}$ according to the following equations:

Immobilized protein (\%): (immobilized protein/loaded protein) $\mathrm{x}$ 100; immobilized activity (\%): (immobilized activity/loaded activity) $x$ 100; activity recovery (\%): (observed activity of the immobilized enzyme/starting activity) $\times 100$.

\section{Specific reaction rate}

The specific reaction rate for batch $\left(r_{\text {batch }}\right)$ was calculated from the amount of the product $(\mathrm{P}, \mu \mathrm{mol})$, the reaction time $(\mathrm{t}, \mathrm{min})$, and the mass of biocatalyst employed $\left(m_{E}, m g\right): r_{b a t c h}=n P / t ~ m_{E}\left(\mu m o l m^{-1}\right.$ $\mathrm{mg}^{-1}$ ). The specific reaction rate for flow biotransformation $\left(r_{\text {flow }}\right)$ was calculated from the concentration of the product ([P], $\mu \mathrm{mol} \mathrm{mL} \mathrm{m}^{-1}$ ), the flow rate $\left(\mathrm{f}, \mathrm{mL} \mathrm{min}{ }^{-1}\right)$, and the mass of protein employed $\left(m_{E}, m g\right): r_{\text {flow }}=[P] \times f / m_{E}\left(\mu \mathrm{mol} \mathrm{min}^{-1} \mathrm{mg}^{-1}\right)$.

\section{Vf-ATA expression and purification}

The amine transaminase from Vibrio fluvialis (Vf-ATA) was produced as previously reported. ${ }^{[57]}$ Briefly, E. coli BL21(DE3) cells carrying the expression plasmid for Vf-ATA were streaked on LB-Agar plates containing kanamycin $30 \mu \mathrm{g} \mathrm{mL}^{-1}\left(\mathrm{LB}_{\mathrm{KAN} 30}\right)$ and incubated overnight at $37^{\circ} \mathrm{C}$. Colonies were aseptically removed, inoculated in $50 \mathrm{~mL}$ of $\mathrm{LB}_{\text {KAN30 }}$ medium and incubated overnight at $37^{\circ} \mathrm{C}$ and $220 \mathrm{rpm}$. The pre-cultures were used for the inoculation of $500 \mathrm{~mL}$ of $\mathrm{LB}_{\text {KAN30 }}$ medium, then incubated at $37^{\circ} \mathrm{C}$ and $220 \mathrm{rpm}$. When the $\mathrm{OD}_{60}$ value was between 0.5 and 1, IPTG ( $0.5 \mathrm{M}$ stock solution) was added till a final concentration of $1 \mathrm{mM}$ to induce the expression. The $V f-$ ATA cultures were incubated at $30^{\circ} \mathrm{C}$ and $220 \mathrm{rpm}$ for $24 \mathrm{~h}$. At the endpoint of the expression, the cells were recovered by centrifugation at $5000 \mathrm{rpm}$ and $4{ }^{\circ} \mathrm{C}$ for $30 \mathrm{~min}$ and resuspended in $20 \mathrm{~mL}$ of washing buffer $(500 \mathrm{mM} \mathrm{NaCl}, 20 \mathrm{mM}$ imidazole, $20 \mathrm{mM}$ potassium phosphate buffer, $\mathrm{pH} 7.0$ ). Cells were lysed by three sonication cycles at $0^{\circ} \mathrm{C}$ and the cell lysate was centrifuged at $10000 \mathrm{rpm}$ and $4^{\circ} \mathrm{C}$ for $30 \mathrm{~min}$. The transaminase was purified by IMAC using $\mathrm{Ni}-$ NTA Sepharose 6 Fast Flow resin (GE Healthcare, Italy) as the stationary phase according to the manufacturer's instruction. The eluates containing the target protein were collected and dialyzed for $16 \mathrm{~h}$ at $4{ }^{\circ} \mathrm{C}$ in $50 \mathrm{mM}$ phosphate buffer $\mathrm{pH}$ 9. After the dialysis, samples were stored at $-80^{\circ} \mathrm{C}$. Protein content was measured 
using the Bio-Rad Protein Assay according to the method of Bradford; bovine serum albumin (BSA) was used as standard protein. Protein purity was verified by SDS-PAGE analysis (10\% T, $2.6 \% \mathrm{C}$ ). The molecular weight protein standard mixture from BioRad (Karlsruhe, Germany) was used as reference. Gels were stained for protein detection with Coomassie Brilliant Blue.

\section{Glyoxyl-agarose preparation}

Glyoxyl-agarose was prepared as reported by Guisan. ${ }^{[59]}$ Briefly, agarose $(10 \mathrm{~g})$ was suspended in deionized water $(2.8 \mathrm{~mL})$ at $4{ }^{\circ} \mathrm{C}$ under mechanical stirring. A $1.7 \mathrm{M}$ solution of $\mathrm{NaOH}(4.8 \mathrm{~mL})$ containing $\mathrm{NaBH}_{4}$ (14.3 $\left.\mathrm{mg} \mathrm{mL}^{-1}\right)$ was added. Etherification was carried out in an ice bath by adding dropwise glycidol $(3.4 \mathrm{~mL})$. The reaction was carried out for $18 \mathrm{~h}$. After the incubation period, the suspension was filtered and the carrier was washed with deionized water. Oxidation was initiated by adding $100 \mathrm{mM} \mathrm{NaIO}$ ( $68 \mathrm{~mL})$. The reaction was carried out for $2 \mathrm{~h}$ at room temperature, then the carrier was filtered under reduced pressure and washed thoroughly with deionized water and stored at $4{ }^{\circ} \mathrm{C}$.

\section{Vf-ATA immobilization on glyoxyl-agarose}

Vf-ATA ( $2 \mathrm{mg} ; 9.3 \mathrm{U}$ ) was incubated with glyoxyl-agarose $(1 \mathrm{~g})$ in $\mathrm{NaHCO}_{3}$ buffer $(\mathrm{pH} \mathrm{10}, 50 \mathrm{mM}, 10 \mathrm{~mL})$ at $4{ }^{\circ} \mathrm{C}$ for $3 \mathrm{~h}$ under mechanical stirring. Chemical reduction of imines was carried out over $30 \mathrm{~min}$ by adding $\mathrm{NaCNBH}_{3}(10 \mathrm{mg})$ to the mixture. The immobilized enzyme was then filtered under vacuum and washed thoroughly with deionized water and $\mathrm{K}_{2} \mathrm{HPO}_{4}$ buffer $(\mathrm{pH} 8,50 \mathrm{mM})$ and stored at $4{ }^{\circ} \mathrm{C}$. The immobilization procedure was monitored by evaluating the residual protein and the residual activity of the supernatant by Bradford ${ }^{[46]}$ and activity assay, respectively. For the flow reactions, a protein loading of $5 \mathrm{mg} / \mathrm{g}$ was used.

\section{Vf-ATA immobilization on Sepabeads ${ }^{\text {TM }}$ EC-EP/S}

Vf-ATA (1 mg; $1.23 \mathrm{U})$ was incubated with Sepabeads ${ }^{\mathrm{TM}}$ EC-EP/S $(1 \mathrm{~g})$, previously hydrated with deionized water $(10 \mathrm{~mL})$ under gentle shaking for $1 \mathrm{~h}$ in phosphate buffer (pH $8,50 \mathrm{mM}, 5 \mathrm{~mL})$, at room temperature for $24 \mathrm{~h}$ under mechanical stirring. The immobilization procedure was monitored by evaluating the residual protein and the residual activity of the supernatant by Bradford assay ${ }^{[46]}$ and activity assay, respectively. The immobilized enzyme was then filtered, washed with deionized water and re-suspended in $\mathrm{K}_{2} \mathrm{HPO}_{4}$ buffer ( $\mathrm{pH} 8.5,50 \mathrm{mM}, 4 \mathrm{~mL}$ ) containing glycine $(3 \mathrm{M})$ and stirred for further $20 \mathrm{~h}$ to quench the unreacted epoxides. ${ }^{[36,43]}$ The biocatalyst was eventually filtered under vacuum, washed thoroughly with deionized water and $\mathrm{K}_{2} \mathrm{HPO}_{4}$ buffer $(\mathrm{pH} 8,50 \mathrm{mM})$ and stored at $4{ }^{\circ} \mathrm{C}$.

\section{Vf-ATA activity assay}

Enzyme specific activity was determined by a spectrophotometric assay (Scheme $\mathrm{S} 1$ ) as previously reported. ${ }^{[45]}$ Briefly, phosphate buffer $(\mathrm{pH} 8,50 \mathrm{mM}, 3 \mathrm{~mL})$ containing sodium pyruvate $(2.5 \mathrm{mM})$, (S)- $\alpha$-methyl benzylamine ((S)-MBA, $2.5 \mathrm{mM})$ and DMSO $(0.25 \% \mathrm{v} / \mathrm{v})$ was poured in a quartz cuvette. Soluble Vf-ATA $(6 \mu \mathrm{L})$ was added and the absorbance of acetophenone $\left(\varepsilon=12 \mathrm{mM}^{-1} \mathrm{~cm}^{-1}\right)$ at $245 \mathrm{~nm}$ was detected for $60 \mathrm{~s}$ under the kinetic mode. One unit (U) is defined as the amount of enzyme which produces one $\mu \mathrm{mol}$ of acetophenone per minute under the above conditions. For the immobilized Vf-ATA, the same assay was performed by using 10$15 \mathrm{mg}$ of the immobilized biocatalyst under magnetic stirring for
$180 \mathrm{~s}$. Enzymatic activity was determined according to Equation (1). The measurements were performed at least in duplicate.

$$
\frac{\mathrm{U}}{\mathrm{mL} \text { or } \mathrm{g}}=\frac{\Delta \mathrm{A} / \mathrm{min} \times \mathrm{Vs}}{\varepsilon \times \mathrm{E}}
$$

Equation 1. $\triangle \mathrm{A} / \mathrm{min}=$ slope of $\mathrm{Abs}$ vs time curve $\left(\mathrm{mAU} \mathrm{min}^{-1}\right), \mathrm{Vs}=$ total assay volume $(\mathrm{mL}), \varepsilon=$ acetophenone molar absorbivity $\left(12 \mathrm{mM}^{-1} \mathrm{~cm}^{-1}\right), \mathrm{E}=$ amount of soluble enzyme $(\mathrm{mL})$ or immobilized enzyme (g)

The activity of Vf-ATA immobilized on Sepabeds ${ }^{T M}$ EC-EP/S was determined by a discontinuous assay. Three aliquots of immobilized Vf-ATA (15 mg) were placed in plastic tubes and the assay solution $(2 \mathrm{~mL})$ was added. The samples were kept under gentle stirring (rotary shaking); every two minutes, a sample was quenched with $\mathrm{HCl}(2 \mathrm{M}, 2 \mathrm{~mL})$ and the absorbance at $245 \mathrm{~nm}$ was registered, as a single reading. Acetophenone ( $\mu \mathrm{mol})$ was quantified by a calibration curve and used to determine the enzyme activity.

\section{Residual activity of Vf-ATA immobilized on glyoxyl-agarose}

A stock solution containing (S)-MBA $(64.5 \mu \mathrm{L}, 500 \mu \mathrm{mol})$, DMSO $(1 \mathrm{~mL})$ in phosphate buffer (pH 8, $100 \mathrm{mM}, 49 \mathrm{~mL})$ and PLP (12.4 mg, $50 \mu \mathrm{mol})$ was prepared. Aliquots $(50 \mathrm{mg})$ of immobilized Vf-ATA were placed in Eppendorf micro tubes and $1 \mathrm{~mL}$ of the stock solution was added to each Eppendorf. The samples were kept under stirring (rotary shaker) at $25^{\circ} \mathrm{C}$. At fixed times, each sample was filtered under vacuum, rinsed thoroughly with distilled water, conditioned with phosphate buffer $(\mathrm{pH} 8,50 \mathrm{mM})$ and dried for 5 min. Residual activity $\left(\mathrm{Ug}^{-1}\right)$ was measured by submitting the filtered immobilized enzyme (10-15 mg) to the spectrophotometric assay as reported above and compared with the activity $\left(\mathrm{U} \mathrm{g}^{-1}\right)$ of the enzyme before incubation, which was considered as $100 \%$.

\section{Batch synthesis of (S)-1-(5-fluoropyrimidin-2-yl)-ethanamine} (3)

1-(5-Fluoropyrimidin-2-yl)-ethanone $1 \quad(28.0 \mathrm{mg}, 200 \mu \mathrm{mol})$ was dissolved in DMSO $(200 \mu \mathrm{L})$ and added to phosphate buffer $(\mathrm{pH} 8$, $100 \mathrm{mM}, 9.8 \mathrm{~mL})$ containing PLP $(4.9 \mathrm{mg}, 20 \mu \mathrm{mol})$ and (S)-MBA 2 $(25.8 \mu \mathrm{L}, 200 \mu \mathrm{mol})$ in a plastic flask. Immobilized Vf-ATA $(652 \mathrm{mg}$ $1.80 \mathrm{U}$ ) was added and the mixture was kept under mechanical stirring. Samples were taken, diluted with bidistilled water $(1: 10)$ and analyzed by HPLC. Once the highest conversion was achieved, the biocatalyst was recovered by filtration under vacuum.

\section{Flow synthesis of (S)-1-(5-fluoropyrimidin-2-yl)-ethanamine} (3)

Immobilized Vf-ATA $(2.0 \mathrm{~g})$ was packed into a glass column (Omnifit, $6.6 \mathrm{~mm}$ i.d. $\times 100 \mathrm{~mm}$ length). The packed-bed reactor was washed with a $100 \mathrm{mM}$ phosphate buffer $\mathrm{pH} 8$ at $100 \mu \mathrm{L} \mathrm{min}^{-1}$ for $10 \mathrm{~min}$. The obtained reactor volume was $2.0 \mathrm{~mL}$. A solution $(100 \mathrm{~mL})$ of 1-(5-fluoropyrimidin-2-yl)-ethan-1-one $(1,20 \mathrm{mM})$, (S)MBA $(2,20 \mathrm{mM})$ and PLP $(1 \mathrm{mM})$ in phosphate buffer (pH 8, $100 \mathrm{mM}$ ) with $5 \% \mathrm{v} / \mathrm{v}$ dimethyl carbonate was prepared. The

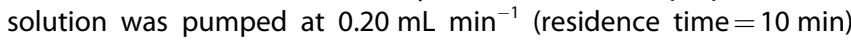
through the bioreactor maintained at $28^{\circ} \mathrm{C}$. The exiting flow stream was directed into a column packed with Dowex Marathon $\mathrm{C}$ resin (reactor volume: $5 \mathrm{~mL}$ ) that was previously activated with $2 \mathrm{M} \mathrm{HCl}$ and washed with $\mathrm{H}_{2} \mathrm{O}$. The desired amine was trapped by the resin At the end of the reaction, the column packed with Dowex Marathon $\mathrm{C}$ resin was washed by flowing $\mathrm{H}_{2} \mathrm{O}$ at $0.25 \mathrm{~mL} \mathrm{~min}{ }^{-1}$ for 
20 min. (S)-1-(5-Fluoropyrimidin-2-yl)-ethanamine 3 was then released using a $1 \mathrm{M}$ solution of $\mathrm{NH}_{4} \mathrm{OH}$ at $0.25 \mathrm{~mL} \mathrm{~min}^{-1}$ for $30 \mathrm{~min}$. The flow stream was collected in fractions of $2.0 \mathrm{~mL}$; TLC assays were performed to select the samples containing the pure product. After evaporation of the solvent, the pure amine was recovered in $35 \%$ isolated yield $(99 \mathrm{mg}) .{ }^{1} \mathrm{H}$ NMR $\left(\mathrm{CDCl}_{3}\right) \delta 8.60(\mathrm{~s}, 2 \mathrm{H}), 4.65(\mathrm{br} \mathrm{s}$, $2 \mathrm{H})$, 4.07-4.15 (m, 1H), $1.20(\mathrm{~d}, 3 \mathrm{H})$.

\section{Chemical synthesis of racemic \\ 1-(5-fluoropyrimidin-2-yl)-ethanamine}

The chemical synthesis of racemic 1-(5-fluoropyrimidin-2-yl) ethanamine was performed slightly modifying a previously reported procedure. $^{[61]}$ i) 1-(5-Fluoropyrimidin-2-yl)-ethan-1-one 1 (200 mg, $1.43 \mathrm{mmol}$ ) was dissolved in $\mathrm{MeOH}(5 \mathrm{~mL})$ at room temperature. The solution was cooled at $0{ }^{\circ} \mathrm{C}$ and $\mathrm{NaBH}_{4}(54 \mathrm{mg})$ was added. The resulting mixture was stirred at room temperature for $1 \mathrm{~h}$. Water $(2 \mathrm{~mL})$ was added and the organic solvent was removed under reduced pressure; the aqueous phase was extracted with EtOAc ( $3 \mathrm{x}$ $3 \mathrm{~mL}$ ). The organic extracts were dried over $\mathrm{Na}_{2} \mathrm{SO}_{4}$ and, after evaporation of the volatiles under reduced pressure, 1-(5-fluoropyrimidin-2-yl)ethan-1-ol was obtained as a red oil (75\% yield). ii) The alcohol obtained from the previous step $(152 \mathrm{mg}, 1.07 \mathrm{mmol}$ ) was dissolved in $\mathrm{CH}_{2} \mathrm{Cl}_{2}(2 \mathrm{~mL})$, and triethylamine $(297 \mu \mathrm{L}, 2.14 \mathrm{mmol})$ was added at room temperature. The solution was cooled to $0{ }^{\circ} \mathrm{C}$, and methanesulfonyl chloride $(100 \mu \mathrm{L}, 1.28 \mathrm{mmol})$ was added dropwise. The resulting mixture was allowed to stir at r.t. for $2 \mathrm{~h}$. The mixture was washed with $1 \mathrm{M} \mathrm{HCl}(2 \times 2 \mathrm{~mL})$, the organic phase was dried over $\mathrm{Na}_{2} \mathrm{SO}_{4}$ and evaporated under reduced pressure to give 1-(5-fluoropyrimidin-2-yl)ethyl methanesulfonate ( $90 \%$ yield). iii) The residue $(212 \mathrm{mg}, 0.96 \mathrm{mmol})$ was dissolved in DMF $(5 \mathrm{~mL})$ and treated with sodium azide $(62 \mathrm{mg}, 0.96 \mathrm{mmol})$. The resulting mixture was stirred at r.t. for $72 \mathrm{~h}$ and was then partitioned between EtOAc $(5 \mathrm{~mL})$ and brine $(10 \mathrm{~mL})$. The organic layer was collected, dried over $\mathrm{Na}_{2} \mathrm{SO}_{4}$, and evaporated under reduced pressure. The crude material was purified by flash column chromatography as a colorless oil (55\% yield). iv) 2-(1-Azidoethyl)5 -fluoropyrimidine $(88 \mathrm{mg}, 0.53 \mathrm{mmol}$ ) was dissolved in $\mathrm{MeOH}$ $(5 \mathrm{~mL})$ and submitted to a hydrogenation reaction in a Thales-Nano

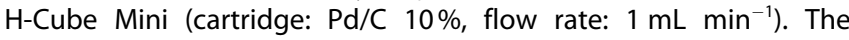
exiting solution was evaporated under reduced pressure to afford racemic 1-(5-fluoropyrimidin-2-yl) ethanamine as a pale yellow oil in quantitative yield. HPLC chiral analysis retention times $\left(t_{R}\right)$ : $(S)$ MBA (2) =3.8 min, (S)-1-(5-fluoropyrimidin-2-yl)-ethanamine $(3)=$ $5.9 \mathrm{~min}$; $(R)-1$-(5-fluoropyrimidin-2-yl)-ethanamine $=6.1 \mathrm{~min}$; 1 - $(5$ fluoropyrimidin-2-yl)-ethan-1-one $(1)=8.0 \mathrm{~min}$.

\section{Analytical methods}

HPLC analyses of batch reactions were performed on a HPLC Chromaster 600 bar System, Merck Hitachi VWR, equipped with a Purospher $^{\circledast}$ STAR RP-18 endcapped $(3 \mu \mathrm{m})$, Hibar HR 100-2.1, UHPLC column, Sorbent Lot No. TA 1822868 (Merck KGaA, Darmstadt, Germany). Injection volume: $2 \mu \mathrm{L}$; mobile phase: $\mathrm{H}_{2} \mathrm{O}+$ TFA $0.05 \%(\mathrm{~A}) / \mathrm{ACN}+$ TFA $0.05 \%(\mathrm{~B})$; gradient conditions: $0-5 \mathrm{~min}$ $100 \% \mathrm{~A} ; 5 \rightarrow 20 \mathrm{~min} 50 \%(\mathrm{~A}) / 50 \%$ (B); flow rate: $0.3 \mathrm{~mL} \mathrm{~min}{ }^{-1} ; \lambda$ : $245-254 \mathrm{~nm}$. Retention times $\left(t_{R}\right)$ : (S)-1-(5-fluoropyrimidin-2-yl)ethanamine $(3)=3.60 \mathrm{~min}, \quad 1$-(5-fluoropyrimidin-2-yl)-ethan-1-one $(1)=13.40 \mathrm{~min},(S)-\mathrm{MBA} \quad(2)=14.37 \mathrm{~min}$, acetophenone $(4)=$ $20.90 \mathrm{~min}$.

HPLC analyses of the flow reactions were performed on a Breeze 2 HPLC System, Waters, equipped with a Waters 2489 UV-vis detector (Waters, Milford, MA) and a Phenomenex Synergi column $(150 \mathrm{~mm}$ $\times 4.6 \mathrm{~mm}, 4 \mu \mathrm{m})$. Injection volume: $10 \mu \mathrm{L}$; mobile phase: $\mathrm{H}_{2} \mathrm{O}+$ $0.05 \%$ TFA (A)/ACN $+0.05 \%$ TFA (B); gradient conditions: 0-9 min
$90 \% \quad(A) / 10 \% \quad(B), \quad 9 \rightarrow 14 \min \quad 50 \% \quad(A) / 50 \% \quad(B) ;$ flow rate: $1.0 \mathrm{~mL} \mathrm{~min}^{-1} ; \lambda: 254 \mathrm{~nm}$. Reaction samples were diluted with a solution $1: 10 \mathrm{H}_{2} \mathrm{O} / \mathrm{ACN}+0.05 \%$ TFA. Retention times $\left(\mathrm{t}_{\mathrm{R}}\right)$ : $(S)-1-(5-$ fluoropyrimidin-2-yl)-ethanamine (3)=2.7 $\mathrm{min}, \quad(S)-\mathrm{MBA} \quad(2)=$ $5.6 \mathrm{~min}, 1$-(5-fluoropyrimidin-2-yl)-ethan-1-one $(1)=7.0 \mathrm{~min}$, acetophenone $(4)=16.4 \mathrm{~min}$.

HPLC chiral analyses were performed using a Jasco PU-980 pump (PerkinElmer, Inc., Waltham, MA) equipped with a UV-vis detector Jasco UV-975 and a Phenomenex Lux Amylose 2 column ( $150 \mathrm{~mm} \times$ $4.6 \mathrm{~mm}, 3 \mu \mathrm{m}$ ). Injection volume: $10 \mu \mathrm{L}$; mobile phase: hexane + $0.5 \%$ diethylamine/iso-propanol $+0.5 \%$ diethylamine, isocratic elu-

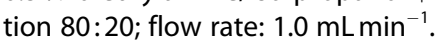

\section{Acknowledgements}

This work was financially supported by Cariplo Foundation (Italy) (Call: "Integrated research on industrial biotechnologies and bioeconomy 2016", project BIOFLOW, ID 2016-0731).

Keywords: biocatalysis • flow chemistry • chiral amines transaminase $\cdot$ immobilization

[1] S. Mathew, H. Yun, ACS Catal. 2012, 2, 993-1001.

[2] E. E. Ferrandi, D. Monti, World J. Microbiol. Biotechnol. 2018, 34, 13.

[3] F. Steffen-Munsberg, C. Vickers, H. Kohls, H. Land, H. Mallin, A. Nobili, L. Skalden, T. van den Bergh, H.-J. Joosten, P. Berglund, M. Hohne, U. T. Bornscheuer, Biotechnol. Adv. 2015, 33, 566-604.

[4] F. Guo, P. Berglund, Green Chem. 2017, 19, 333-360.

[5] J. S. Shin, B. G. Kim, Biotechnol. Bioeng. 1997, 55, 348-358.

[6] P. Domínguez de María, G. de Gonzalo, A. R. Alcántara, Catalysts 2019, 9, 802.

[7] C. K. Savile, J. M. Janey, E. C. Mundorff, J. C. Moore, S. Tam, W. R. Jarvis, J. C. Colbeck, A. Krebber, F. J. Fleitz, J. Brands, P. N. Devine, G. W. Huisman, G. J. Hughes, Science 2010, 329, 305-309.

[8] M. Girardin, S. G. Ouellet, D. Gauvreau, J. C. Moore, G. Hughes, P. N. Devine, P. D. O'Shea, L. C. Campeau, Org. Process Res. Dev. 2013, 17, 6168.

[9] L. Frodsham, M. Golden, S. Hard, M. N. Kenworthy, D. J. Klauber, K. Leslie, C. Macleod, R. E. Meadows, K. R. Mulholland, J. Reilly, C. Squire, S Tomasi, D. Watt, A. S. Wells, Org. Process Res. Dev. 2013, 17, 1123-1130.

[10] Y. Feng, Z. Luo, G. Sun, M. Chen, J. Lai, W. Lin, S. Goldmann, L. Zhang, Z. Wang, Org. Process Res. Dev. 2017, 21, 648-654.

[11] Z. Peng, J. W. Wong, E. C. Hansen, A. L. A. Puchlopek-Dermenci, H. J. Clarke, Org. Lett. 2014, 16, 860-863.

[12] J. Limanto, E. R. Ashley, J. Yin, G. L. Beutner, B. T. Grau, A. M. Kassim, M. M. Kim, A. Klapars, Z. Liu, H. R. Strotman, M. D. Truppo, Org. Lett. 2014, 16, 2716-2719.

[13] M. D. Truppo, H. Strotman, G. Hughes, ChemCatChem 2012, 4, 10711074.

[14] X-J. Zhang, H-H. Fan, N. Liu, X-X. Wang, F. Cheng, Z-Q. Liu, Y-G. Zheng, Enzyme Microb. Technol. 2019, 130, 109362.

[15] M. D. Truppo, J. M. Janey, G. Hughes, WO2012177527A1 2012.

[16] M. D. Truppo, M. Journet, H. Strotman, J.P. McMullen, S. Grosser, WO2014133928 A1 2014.

[17] S. A. Kelly, S. Pohle, S. Wharry, S. Mix, C. C. R. Allen, T. S. Moody, B. F. Gilmore, Chem. Rev. 2018, 118, 349-367.

[18] R. E. Meadows, K. R. Mulholland, M. Schürmann, M. Golden, H. Kierkels, E. Meulenbroeks, D. Mink, O. May, C. Squire, H. Straatman, A. S. Wells, Org. Process Res. Dev. 2013, 17, 1117-1122.

[19] J.-S. Shin, B.-G. Kim, Biosci. Biotechnol. Biochem. 2001, 65, 1782-1788.

[20] K. S. Midelfort, R. Kumar, S. Han, M. J. Karmilowicz, K. McConnell, D. K. Gehlhaar, A. Mistry, J. S. Chang, M. Anderson, A. Villalobos, J. Minshull, S. Govindarajan, J. W. Wong, Protein Eng. Des. Sel. 2013, 26, 25-33.

[21] A. Nobili, F. Steffen-Munsberg, H. Kohls, I. Trentin, C. Schulzke, M. Höhne, U. T. Bornscheuer, ChemCatChem 2015, 7, 757-760. 
[22] D. Koszelewski, K. Tauber, K. Faber, W. Kroutil, Trends Biotechnol. 2010, 28, 324-332.

[23] A. P. Green, N. J. Turner, E. O'Reilly, Angew. Chem. Int. Ed. 2014, 53, 10714-10717; Angew. Chem. 2014, 126, 10890-10893.

[24] M. D. Truppo, J. D. Rozzell, N. J. Turner, Org. Process Res. Dev. 2010, 14, 234-237.

[25] L. Tamborini, P. Fernandes, F. Paradisi, F. Molinari, Trends Biotechnol. 2018, 36, 73-88.

[26] P. Žnidaršič-Plazl, Biotechnol. J. 2019, 14, 1800580

[27] J. M. Woodley, Curr. Op. Green Sus. Chem. 2020, 21, 22-26.

[28] J. M. Woodley, Appl. Microbiol. Biotechnol. 2019, 103, 4733-4739.

[29] Z. Molnár, E. Farkas, Á. Lakó, B. Erdélyi, W. Kroutil, B. G. Vértessy, C. Paizs, L. Poppe, Catalysts, 2019, 9, 438.

[30] L. van den Biggelaar, P. Soumillion, D. P. Debecker, Catalysts 2017, 7, 54.

[31] L. van den Biggelaar, P. Soumillion, D. P. Debecker, RSC Adv. 2019, 9, 18538-18546.

[32] J. Britton, S. Majumdar, G. A. Weiss, Chem. Soc. Rev. 2018, 47, $5891-$ 5918.

[33] C. Mateo, J. M. Palomo, M. Fuentes, L. Betancor, V. Grazu, F. Lopez Gallego, B. C. C. Pessela, A. Hidalgo, G. Fernandez-Lorente, R. FernandezLafuente, J. M. Guisan, Enzyme Microb. Technol. 2006, 7, 274-280.

[34] E. Katchalski-Katzir, D. M. Kraemer, J. Mol. Catal. B 2000, 10, 157-176.

[35] F. Dall'Oglio F, M. L. Contente, P. Conti, F. Molinari, D. Monfredi, A. Pinto, D. Romano, D. Ubiali, L. Tamborini, I. Serra, Catal. Commun. 2017, 93, 29-32.

[36] M. Planchestainer, M. L. Contente, J. Cassidy, F. Molinari, L. Tamborini, F. Paradisi, Green Chem. 2017, 19, 372-375.

[37] O. Barbosa, R. Torres, C. Ortiz, Á. Berenguer-Murcia, R. C. Rodrigues, R. Fernandez-Lafuente, Biomacromolecules 2013, 14, 2433-2462.

[38] S. Velasco-Lozano, A. I. Benítez-Mateos, F. López-Gallego, Angew. Chem. Int. Ed. 2017, 56, 771-775; Angew. Chem. 2017, 129, 789-793.

[39] V. V. Mozhaev, in Stability and Stabilization of Biocatalysts. Progress in Biotechnology, Vol. 15, (Eds.: A. Ballesteros, F. J. Plou, J. L. Ibor, P. J. Halling), Elsevier Science B. V., Amsterdam, 1998, pp 355-363.

[40] I. Serra, S. Daly, A. R. Alcantara, D. Bianchi, M. Terreni, D. Ubiali, RSC Adv. 2015, 5, 23569-23577.

[41] S. Chen, J. C. Campillo-Brocal, P. Berglund, M. S. Humble, J. Biotechnol. 2018, 282, 10-17.

[42] S. Cantone, V. Ferrario, L. Corici, C. Ebert, D. Fattor, P. Spizzo, L. Gardossi, Chem. Soc. Rev. 2013, 42, 6262-6276.

[43] C. Mateo, V. Grazù, J. M. Palomo, F. Lopez-Gallego, R. FernàndezLafuente, J. M. Guisàn, Nat. Protoc. 2007, 2, 1022-1033.
[44] E. Abaházi, P. Sátorhelyi, B. Erdélyi, B. G. Vértessy, H. Land, C. Paizs, P. Berglund, L. Poppe, Biochem. Engin. J. 2018, 132, 270-278.

[45] S. Schätzle, M. Höhne, E. Redestad, K. Robins, U. T. Bornscheuer, Anal. Chem. 2009, 81, 8244-8248.

[46] M. M. Bradford, Anal. Biochem. 1976, 27, 248-254.

[47] C. Csajági, G. Szatzker, E. R. Töke, L. Ürge, F. Darvas, L. Poppe, Tetrahedron: Asymmetry 2008, 19, 237-246.

[48] M. Höhne, K. Robins, U. T. Bornscheuer, Adv. Synth. Catal. 2008, 350 807-812.

[49] G. Ottolina, S. Riva, in Methods Non-Aqueous Enzymol. (Ed.: M. N. Gupta), Birkhäuser Basel, Basel, 2000, pp. 133-145.

[50] Y. Mao, M. Krischke, C. Hengst, U. Kulozik, Food Chem. 2018, 253, 194 202.

[51] K. Faber, Biotransformations in Organic Chemistry: A Textbook, Springer, Berlin, 2011.

[52] P. Jacob, J. Org, Chem. 1996, 61, 2916-2917.

[53] S.-T. Chen, W.-H. Huang, K.-T. Wang, J. Org, Chem. 1994, 59, 7580-7581.

[54] S. Shen, K. Soda, J. Chem Soc, Chem. Commun. 1983, 82-83.

[55] A. Basso, W. Neto, S. Serban, B. D. Summers, Chim. Oggi - Chem. Today 2018, 40-42.

[56] D. Monti, M. C. Forchin, M. Crotti, F. Parmeggiani, F. G. Gatti, E. Brenna, S. Riva, ChemCatChem 2015, 7, 3106-3109.

[57] E. E. Ferrandi, A. Previdi, I. Bassanini, S. Riva, X. Peng, D. Monti, Appl. Microbiol. Biotechnol. 2017, 101, 4963-4979.

[58] D. Koszelewski, I. Lavandera, D. Clay, D. Rozzell, W. Kroutil, Adv. Synth Catal. 2008, 350, 2761-2766.

[59] J. M. Guisàn, Enzyme Microb. Technol. 1988, 10, 375-382.

[60] R. A. Sheldon, S. van Pelt, Chem. Soc. Rev. 2013, 42, 6223-6235.

[61] S. loannidis, M. L. Lamb, T. Wang, L. Almeida, M. H. Block, A. M. Davies, B. Peng, M. Su, H.-J. Zhang, E. Hoffmann, C. Rivard, I. Green, T. Howard, H. Pollard, J. Read, M. Alimzhanov, G. Bebernitz, K. Bell, M. Ye, D. Huszar, M. Zinda, J. Med, Chem. 2011, 54, 262-276.

Manuscript received: November 2, 2019

Revised manuscript received: December 13, 2019

Accepted manuscript online: December 18, 2019

Version of record online: 


\section{FULL PAPERS}

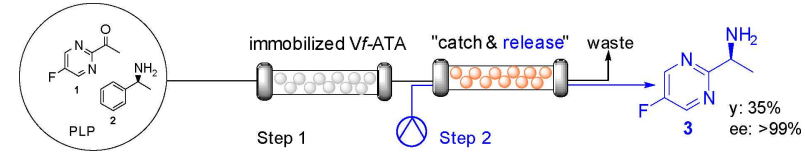

All-in-One: The amine transaminase from Vibrio fluvialis (Vf-ATA) was covalently immobilized and used in the synthesis of (S)-1-(5-fluoropyrimidin-2yl)-ethanamine (3) in a flow system.
Coupling of the continuous flow biotransformation with an in-line purification step resulted in a highly productive and straightforward bioprocess.
R. Semproli, G. Vaccaro, Dr. E. E. Ferrandi, M. Vanoni, Dr. T. Bavaro, Dr. G. Marrubini, F. Annunziata, Prof. P. Conti, Prof. G. Speranza, Dr. D. Monti*, Prof. L. Tamborini*, Prof. D. Ubiali*

$1-10$

Use of Immobilized Amine Transaminase from Vibrio fluvialis under Flow Conditions for the Synthesis of (S)-1-(5-Fluoropyrimidin-2-yl)ethanamine 